\title{
COVID- 19 PANDEMIC AND THE PRECARITY OF LIFE: RETHINKING A Pedagogy of Compassion so That The People of This Earth May LIVE
}

\author{
Bekithemba Dube ${ }^{1)}$, Nathan Moyo ${ }^{2)}$ \\ 1) University of the Free State, South Africa \\ E-mail:_dubeb@ufs.ac.za \\ 2) University of the Free State, South Africa \\ E-mail: bekithembadube13@gmail.com
}

\begin{abstract}
This article interrogates humanity's individual and collective responses to the outbreak of the COVID-19 pandemic, which has been unprecedented in its deadly, unstoppable spread. Widespread illness and deaths across the world as a result of COVID- 19 have invoked grim reminders of our mutual vulnerability The article reimagines a pedagogy of compassion informed by the principles of Ubuntu. In the conclusion, the article reflects on how the pandemic may have brought out the best in humanity, as our mutual vulnerability has taught us to care for each other.
\end{abstract}

Keywords: COVID- 19; Precarity of life; Pedagogy of compassion; Ubuntu and Zimbabwe

\section{INTRODUCTION}

"Dear All,

Whenever you find a Person Infected with Covid 19 in your neighborhood/workplace, being taken to Quarantine/Isolation Center in an Ambulance.

Please do not take Video or Pictures, in fact discourage the person who you find making a video/taking photos.

Don't embarrass the person.

Instead stand in your Balcony or at your Window or your Gate a few feet away and give him/her a thumbs up, Wish him/her good luck and a Speedy Recovery.

Because the way the virus is spreading, soon you will find an ambulance in front of everybody's Gate/Doorstep.

Please understand how this person must be going through.

Kindly:

1. Respect him/her

2. Pray for Him/her

3. Make him/her feel you are a good human being

4. Do not spread panic and "fear of insult" among others.

The person is just unwell, not a criminal. He/she will be cured but the memory of how people treated him/her, will stay with him/her forever!!

We are all in this fight together!!

Let's spread love and build confidence. God bless You!

Be Safe, Stay at Home”, Maintain Social Distancing \& wear your mask”. (Kaligayahan 2020, online)
The poetic, yet sombre stanzas that constitute the epigraph of this paper were circulated in various social media groups in Zimbabwe, as a passionate appeal for compassionate behaviour in the face of unprecedented hospitalisations and deaths as a result of the COVID-19 pandemic. This sombre appeal was evoked by seemingly cavalier and spectatororiented attitudes of social media users sharing statistics and videos of people who had been affected by the coronavirus. It was as if loss of human life was a mere statistical event. An equally malignant expression of such a cavalier attitude is what Claravall and Evans-Amalu (2020, p. 44) describe as the "tsunami of hate and xenophobia" against people of Asian descent in the wake of the COVID- 19 pandemic. In a similar way, BBC News reported that Africans living in China were being targeted by Chinese nationals, hounded out their dwellings and accused of being the spreaders of the pandemic (Vincent, 2020; Ndlovu-Gatsheni, 2020). These cases underscore the dearth of compassion that seems to have become a characteristic of our technological-driven societies, including that of Zimbabwe. Maarouf et al. (2020, p. 2) explain that, in the first weeks of the pandemic, the world's response was one of

"utmost curiosity, concern, and trepidation; sometimes also with a pinch of indifference, for the problem, after all, to some heart-hardened-screen-observers is part of the other's problem, who dies of the virus behind the screen: you scratch the screen, and nothing comes out."

The world, with all its advanced technologies, had no immediate way to prevent or stop the deadly novel COVID-19 pandemic, which had originally originated in Wuhan, China, 
and subsequently spread to all corners of the globe. Suddenly, all human life across this Earth, irrespective of race and gender, was rendered precarious and vulnerable (Butler, 2020). What had apparently been the "privilege of spectatorship" watching social media images from the comfort of one's home (Maarouf et al. 2020, p. 2) - soon gave way to new realisations when the World Health Organization declared the pandemic a global disaster on 11 March 2020. Consequently, many countries closed their borders, imposed lockdown and issued stay-at-home orders for towns and cities. These orders made it apparent that the pandemic was more than a biological phenomenon (Moisio, 2020, p. 1), that the pandemic had become a social and medical disaster. In graphic terms, Connell (2020: 3) writes of "hospitals jammed with COVID19 cases - [and] stories of nurses and doctors engaged in triage, choosing who would get treatment, and turning away very sick people, especially old people, who were left to go home and die".

Medical staff were forced to take this route because of a shortage of the ventilators that offered a modicum of hope to patients in intensive care who were in need of assisted breathing; they had to make the difficult decision who could get ventilators and who could not. This ghastly account evokes Judith Butler's notion of the differential grievability of life (2009, p. 26), as well as a stark reminder of the precarity of human life on this Earth. The question became: Who should live and who should die? The lives of Africans in the Global South, who face perennially inadequate medical facilities and fragile socio-economic infrastructures, were/are especially vulnerable to the pandemic, and their risk of disease was particularly high.

This paper appropriates Judith Butler's motif of the differential grievability of life (2009) to reimagine a pedagogy of compassion that foregrounds nurturance of people who are afflicted and marginalised in the face of the COVID-19 pandemic. Compassion is conceptualised in this paper as being more than feeling pity for the other, but as a powerful, deeply felt call that compels one to action, from being a spectator, to an agentive participant (Zembylas, 2013a) in pursuit of redress for afflicted people. The paper draws on the triadic intersection of the politics of life (Butler, 2020), the politics of pandemics (Kapiriri \& Ross, 2020; Santiago \& Smith, 2020), and the politics of vulnerability (Butler, 2004; Zembylas, 2013a) to reimagine a pedagogy of compassion (Jansen, 2008; Zembylas, 2013a), which could serve as a potentially life-saving safety net, and provide nurturance and succour in the face of vulnerability.

The entry point to the paper is Butler's (2004) assertion that "lives are by definition precarious and therefore vulnerable", and that this sense of precarity is heightened in times of war or pandemic. As Zembylas (2013a, p. 513) posits, the "idea of common vulnerability puts in perspective the notion of all of us as vulnerable, rather than the individual-other who needs our compassion". Yet, in the midst of the COVID-19 pandemic, 'the politics of life' played out: the lives of the elderly were perceived as more vulnerable and, at the same time, less mournable - and therefore "lose-able" and "ungrievable" (Butler, 2009, p. 31).
This paper's primary interest is not unpacking and regurgitating the factors that have historically served to label some lives as more grievable and others as less grievable, with vectors such as race, class and sex being commonly employed in this equation. Rather, the primary interest is in humanity's collective response to those whose lives faced immediate precarity when the pandemic became a grim reminder of our mutual interdependence, and our mutual vulnerability as a people on this Earth. Global vulnerability reminded us that no one was immune to the virus, given our visceral proximity and interdependence. Therefore, the critical issues became: How would humanity respond collectively to a pandemic that portended mutual vulnerability and, therefore, mutual destruction of life on this Earth? Could humanity afford to be apathetic, cynical and indifferent to the suffering of griefstricken families who, alone and afraid, were not allowed to bid farewell to people who had mattered in their lives? And what of the brave health personnel, who became 'frontline' warriors as they battled a pandemic that they could easily fall prey to via the very patients whose lives they were trying to save, and often had to face with inadequate personal protective clothing to ensure their own safety? Would those upon whose shoulders was thrust the responsibility of leadership at national and international levels act compassionately, to give succour and sustenance to humanity, which had become vulnerable? The very moral fibre of society, and our resolve as human beings were, thus, on trial because of the pandemic - with the supreme and yet tragic irony that, to attempt to save a life was to risk losing your own and, even worse, risking infecting your loved ones, so that they, too, could lose their lives.

The precariousness of human life and its vulnerability reached unprecedented levels and, as such, demanded responsible and compassionate leadership. Precarity and vulnerability became part of our lived realities as we endeavoured to ensure we did not contract the virus that had, at that time, no vaccine. It is against this backdrop, of hitherto unimagined global precarity of life, that this paper reimagines a pedagogy of compassion that relates to nurturance and care, so that people of this Earth may live. Thus, the paper seeks to address the following research questions:

How could compassionate pedagogy enhance survival of all in the horrendous times of the COVID-19 pandemic?

How can education rethink a pedagogy of compassion that recognises the precarity of all lives on this Earth?

In what ways have responses to the pandemic in Zimbabwe been informed by a pedagogy of compassion (or not)?

These questions are critical for challenging humanity to rethink, broadly, our social interactions that been, of late, characterised by a seemingly frightening disregard for the sanctity of life. This disregard has been manifested through individualism, the cold logic of the market, and technologydriven media representations of the suffering of the other. The paper's argument is that the COVID-19 pandemic has exposed a cynicism and selfishness that has gripped our societies, and that there is need for a combative ontology of compassion that values the mutual care of all, so that the people of this Earth may live. In the context of Zimbabwe, the philosophy of 
Ubuntu could be the basis of such a combative ontology of compassion. The paper, thus, makes a contribution to the powerful agentive scholarship of emotion and affect that is intended to cause discomfort, and that moves us from spectatorship to witnessing, testifying and acting to bring relief to those who are afflicted. The work of Zembylas (2013a; 2013b), among other scholars, is illustrative of this imperative for humanity to act in compassionate ways.

The rest of the paper is organised as follows. The preceding section introduced the problem by providing background and the research questions. The following section briefly reviews the literature on the pedagogy of compassion, in order to establish its heuristic potential in the face of precarity. This section is then by the theoretical framework that informs the paper. The next section presents selected narratives of pain that have been occasioned by the pandemic. In the discussion section, the paper reflects on the ways a pedagogy of compassion could be enacted in Zimbabwe - a country located in the Global South. The paper concludes by reflecting on how the pandemic may have brought the best out of humanity, as we learn to care, each for the other. First, however, we present a brief background about Zimbabwe, the country of our primary focus.

\section{Zimbabwe in Perspective}

The focus on Zimbabwe is particularly illustrative of how the Global South was ill-prepared for the pandemic. Zimbabwe is a country in southern Africa, which, since its attainment of independence in 1980, has moved rapidly from one of the brightest and promising postcolonial states, to a sorry basket case, with ever-worsening levels of poverty, and crumbling infrastructure, health and education facilities. The socio-economic status of the people had been subjected to severe strain by hyperinflation in 2008, and although gains were made during the government of nationality between 2009 and 2013, these gains had since been undermined by the return to the local currency in 2016. Medical personnel were already involved in prolonged industrial action at the beginning of 2020, and demanded better salaries and conditions of service. The plight of the Zimbabwean state is aptly captured in Santiago and Smith's assertion that,

"poorer countries and communities in the Global South that are already burdened with precarious access to health-care services and limited infrastructure and resources to prevent, diagnose, and treat infectious diseases are those deemed most at risk to the spread of COVID-19" (2020, p. 89).

For a country with an erratic water supply, even in urban areas, it was evident that strategies to contain COVID have not worked in Global South (Santiago \& Smith, 2020). At the time of writing this paper (May 2021), Zimbabwe, with an estimated population of 14 million, had registered 38572 cases, 1582 deaths and 36349 recoveries against the global infection of 164 million, and 3.39 million . The following section outlines the notion of a pedagogy of compassion that is reimagined as humanity's collective response to the distress and suffering of the other.

Pedagogy of Compassion for Enhancement of Life
As the grim realities of the COVID-19 became clearer, the 'spectator attitude' that had characterised initial responses gradually gave way to, first, pity and then, action, as people grudgingly stayed at home and wore masks in public spaces. The sense of our common vulnerability triggered a sense of action that protects the self from harm and, at the same time, leads us to identify with the suffering of the other. It is at this point that compassion became a new characteristic response to the pandemic.

In this paper, we foreground the explanation by Claravall and Evans-Amalu (2020, p. 44) that "compassion is taking mindful action to alleviate the struggles and sufferings of others". We aver that compassion is the emotive feeling that arises out of difficulty, when the vulnerability of the other is evident and compels us to action. As Butler (2004, p. 29) explains, "each of us is constituted politically in part by virtue of the social vulnerability of our bodies. ... We cannot ... will away this vulnerability. We must attend to it". Compassion is, thus, a compulsive reaction that arises when we are witness to another's suffering, and are, thus, impelled by an inner drive that is essentially human to take action to help, thus, becoming agentive participants (Zembylas, 2013a, p. 505). It is for this reason that we are in favour of a pedagogy of compassion, and not a 'pedagogy of pity', as pity is mere sympathy, unaccompanied by action (Zembylas, 2013a).

A pedagogy of compassion in the face of the COVID-19 pandemic is, therefore, about how we can acknowledge our common vulnerability, and then take action that seeks to give succour where continuing to live has become precarious. Papastephanou et al. (2020, p. 4) extends the agentive component of compassion, by rethinking what he calls a "pedagogy of precarity" as synonymous with a "pedagogy for justice". Such an assertion resonates with the notion of compassion as a fight for justice. A reimagined pedagogy of compassion is, thus, about how humanity responds collectively to the pandemic, and in ways that enhance living on this Earth. The pedagogy of compassion, when framed as a fight for justice, becomes deeply implicated in the triadic intersection of the politics of life, the politics of pandemics, and the politics of vulnerability, as the theoretical framework below illustrates.

\section{THEORETICAL FRAMEWORK}

The theoretical framework employed in this paper is undergirded by the notion of 'politics', in order to highlight power dynamics and consequent contestations that arise from and characterise decision-making in relation to the distribution of resources - including who is advantaged or disadvantaged by the particular policy choices being made. The interplay of various vested interests manipulate or seek to influence structures of power, such that reality is ultimately perceived in particular ways that work to the advantage of those who wield that power, while those at the margins bear the negative consequences of that politics. Thus, when pandemics occur, they bring to the fore the "politics of pandemics" (Kapiriri \& Ross, 2020, p. 733), which is understood as "the extensive and diverse influence of local, national, and international governments and organizations, on the health outcomes of 
communities during disease outbreaks". The politics of pandemics is really about the "political processes and politicking that underlie public health decisions ... numerous ethical and political implications are embedded in the decisions that societies make to address pandemics" (Santiago $\&$ Smith, 2020, p. 90). Therefore, responses to a pandemic ultimately reflect the influence of power and privilege on those whose lives are most directly threatened by the pandemic (Kapiriri \& Ross, 2020).

In some instances, the politics of blame is added to the mix, as particular groups, be they ethnic or racial, are blamed for the origin or outbreak of the disease. It is for this reason that Dodds et al. (2020, p. 292) assert that "interpreting and responding to pandemics is always a political act". In the case of COVID-19, the coronavirus was dubbed the Chinese virus (Estelles \& Fischman, 2020) in an example of the politics of blame during a pandemic. It is such claims that give rise to the 'politics of life', as the urgency of intervention, and the level of intervention needed to save lives, becomes a 'political game' played by the people whose lives may not be threatened most in the first instance. As Butler (2020b) explains with regard to the COVID-19 pandemic in the United States, 'the politics of life' is apparent in the explicit and insidious power over life and death that the pandemic exposes in economic and racial terms.

In Butler's view, there are health systems that let people die due to failure to institute health care as a public good that ought to be funded by the state. Thus, in this equation of life, both pandemic politics and the politics of life are engaged in a complex, yet systemic interplay that results in vulnerability, framed as the potential to be harmed by another. Hence, the politics of vulnerability emanates from these vectors, as illustrated in Figure 1. Following Butler's admonition, we ought to reframe the politics of life as a reflection of the shared conditions of life, in which we all face a common vulnerability.

In the triangular matrix of the politics identified, in Figure 1, we have deliberately located PRECARITY at the heart of the matrix, to underscore its salience as an inevitability that is constituted by and radiates from all the 'politics' to which human life is subject. Precarity stands as reminder of how all lives are grievable in the COVID-19 pandemic. Precarity is, thus, framed to refer to "the politically induced condition in which certain populations suffer from failing social and economic networks of support and become deferentially exposed to injury, violence and death" (Butler, 2009, p. 27). Hence, the notion of differential grievability that is employed as the motif in this paper arises directly from the precarity of lives that is induced by failing social and economic conditions. All the arrows in the diagram in Figure 1 point to the pedagogy of compassion, as the collective human response to suffering. Such a matrix of factors is critical in understanding the vulnerability of all lives at this time of the COVID-19 pandemic and, in particular, the Zimbabwean situation that is the focus of this study.

How can a compassionate pedagogy, framed as a fight for justice, constitute an interventionist strategy to challenge this triadic intersection of the politics of pandemics, the politics of life and the politics of vulnerability? We posit that the vulnerability that the people of this Earth face at the height of the pandemic is not just the outcome of natural forces, but the result of conscious political decisions that are representative of the power dynamics governing the world - occasioned mainly by the dearth of compassion that characterises a neoliberal world that is controlled by market forces. Gibson and Cook-Sather (2020, p. 20) remind us that compassion is "beyond merely feeling concern for others", and encompasses action, in that it "requires one's strength to be with the suffering". It is through narratives of pain and grief that people may be persuaded to act compassionately in ways that may give succour to life. In the following section, we present scenes of grief that are representative of compassion.

COVID-19 Narratives of Pain and Consequent Compassion

One of the outcomes of the COVID-19 pandemic is the generally restricted burial practices of people who had succumbed to the virus. That spectre of dying, alone, with only a couple of detached medical personnel, who also fear for their own lives, became the sad ending of many lives. Some narratives of pain, grief and loss were lived and experienced graphically on CNN on 4 April 2020, as well as privately, in letters that circulated on social media. In the midst of their grief, some individuals were moved by a sense of compassion, not for themselves, but for the rest of humankind, with whose common vulnerability they identified. They were moved with a desire to talk and write, because they felt that they had something important to share. We recount two episodes that are graphic illustrations of compassion. Episode 1 is Maura Lewinger, who lost her husband to the pandemic.

Episode 1: On 4 April 2020, CNN viewers were stunned when show host Erin Burnett sobbed as she interviewed Maura Lewinger, who had lost her 42-year-old husband to the coronavirus. Lewinger, in her grief, was convinced that she had to act, so that the people of this Earth could live. While admittedly shattered, her emotional appeal was simple and profound:

"People are just not being careful. People are being so invincible - feeling and they think it can't happen to them. You cannot be with people that are not in your house. As sad and lonely and everything that it is, you must, must stay with only the people in your house" (CNN, 2020 online).

Maura Lewinger's powerful message is that the people of New York should take the killer virus seriously and stay home. This message was expressed at a time when New York was the epicentre of the virus in the United States, and the United States had become the epicentre of the worldwide pandemic. Of particular interest to us in this paper is the compassion that Mary Lewinger showed for her fellow residents. Even in her grief, she cared enough to state that other lives could and should be saved if people took action. Such action is at the root of the pedagogy of compassion that is argued for in this paper.

The salience of this interview is that it highlights how a public pedagogy of compassion was set in motion by the act of Mauria Lewinger sharing her grief in public. As was 
reported later, a procession of 131 cars drove by her home in solidarity and to mourn a man whose funeral they could not attend because of lockdown regulations. What these events highlight is a pedagogy of compassion that resulted from and was manifested when people realised their common vulnerability. The life of Joseph Lewinger was rendered mournable in ways that made the people of New York come together to thank health workers, who were brave enough to continue working in hospitals to save lives, even as their own lives were threatened. It became a common and profound occurrence for people to wave for health workers to express their gratitude for the work the health workers were doing. For example, on 28 April 2020, the US Navy Blue Angels and Air Force flew over New York City to salute COVID-19 frontline workers (NPR, 2020).

Episode 2: The second narrative of pain and grief is drawn from a Zimbabwean doctor who lives and works in the diaspora. He also suffered unbearable loss when his spouse succumbed to the virus. She was a health worker who probably contracted the virus while in the line of duty. Having experienced such a shattering loss, the doctor decided to pen a letter to his compatriots in Zimbabwe. The letter, headed Dying alone with no family around the evils of corona virus, is abridged for purposes of length (1st TV, 2020).

My wife spent 10 days dying. She was 44 and she had worked for NHS here in England for over ten years. She adored, her husband and we had established a strong family life. Without her we feel life is a lot less worth living.

My wife had never been bedridden before. She only went to hospital to treat others but now tables had changed.

For 10 days my son and I sat by the table holding hands. No relative could come to see us we are in Lockdown.

Because it was Corona no visitations we're allowed.

This day the doctor called he said things were very bad. He then said My job," the doctor said, "is about prolonging people's lives. Anything I give to your wife now would simply be prolonging her death." When it finally came, death was quite sudden, and absolutely unmistakable. But those 10 days were hard. Death is foreign to us now; most of us do not know what it looks, sounds and smells like. We certainly don't like talking about it. But the call came my wife was gone. She died alone in a hospital surrounded by strangers.

I looked at my son and I did not know how to tell him. I simply said to him son God has done his will. He looked at me and said God's will is great when is mum coming home. My tears ran down my cheeks. Nobody could come to comfort me. I had to be strong for my son.

My son penned these words to his friends. I cried uncontrollably when I read the words.

It was one cold winter night on that day mum got sick. She was taken from home with promise to come back. My dad told me days later that mum was not coming back. She died at the place she had spent most of time in. Hospital. There is no one like mother to me. I know there is no one like mother to me. Dear God in heaven please look down upon me and my dad.

Dying this time is indeed painful and wounding it destroys the respect given to our dead.
Several factors may have motivated the writing of this letter, yet it is inescapable that that one of Dr Mavaza's motives was to admonish the people of Zimbabwe, to warn them to be wary of the pandemic. If such a death could occur in the United Kingdom, then what would be the chances of survival in Zimbabwe, with its ravaged medical facilities? The depiction of that horror of dying alone, and not in the arms of a loved one, is intended by the author to highlight the grim realities of the pandemic and, thereby, to persuade Zimbabweans to exercise caution, so that they could avoid experiencing such a sad loss. Ingrained in this narrative is not self-pity at the loss of a loved one, but a passionate desire that that others may live on this Earth.

In the two episodes presented above, we infer a commitment to compassion by those who have already suffered loss. Such practices of compassion at individual level resonate with Zembylas's (2013a) notion of a critical pedagogy of compassion. The deep-seated desire is to influence for the public good, which, in this case, is the life of the other. In the discussion section that follows, we reflect on how a reimagined pedagogy of compassion could work in Zimbabwe's troubled politic and economic terrain.

\section{DISCUSSION}

The history and politics of pandemics shows that societies with fairly well-developed social and economic infrastructures are better positioned to respond to the horrors of a pandemic, than societies with fragile socio-economic structures. This was apparent in Zimbabwe, when the outbreak of the COVID-19 pandemic coincided with long-running industrial action by health workers. The cause of the action is cited as the paltry salaries offered to workers by the government, as well as dangerous working conditions, and a shortage of medicine and equipment (Zenda, 2020). Prominent casualties of the COVID-19 pandemic in Zimbabwe included Makamba, son of a former member of Parliament and the country's minister of Lands and Agriculture, Perrence Shiri, which received widespread coverage in local media. At the time of writing, two more government ministers had succumbed to the pandemic. A Zimbabwean journalist writing from the United States remarked as follows:

"That such a prominent public official, one of the privileged few with access to exclusive private health facilities, had fallen to the pandemic sent shivers down the spins of ordinary citizens who depend entirely on the country's decrepit public health facilities that are now practically closed" (Zenda, 2020, p. 1).

The deaths of the well-to-do, who could afford the latest life-saving machines, ventilators and oxygen, while quite alarming to the ordinary person, is, in our view, significant in two respects. First, the pandemic had underscored the precarity of all lives, irrespective of political influence or status. Second, it echoes the motif of differential grievability of life in Zimbabwe, premised on the unequal and skewed provision of medical facilities. Because of their high socioeconomic and political status in Zimbabwean society, the lives of Makamba and Shiri were thus 'mournable'. Dodds et al. (2020, p. 289) explain this phenomenon as an expression of 
"the inbuilt inequalities of contemporary capitalist society in terms of mortality, illness and recovery". In the words of Butler (2004), it is "only the dead we can mourn publicly, the bodies we are allowed to bury, [that] count as human".

It is possible that others, of a lesser status, died slow and painful deaths because they could not access health facilities in Zimbabwe. Such facts are illustrative of the complicity of Zimbabwe's leadership in the worsening of the pandemic the precarity of lives was partly induced by failing social and economic conditions. The way the grievances of the health workers was handled was far from satisfactory; government's response lacked both a sense of urgency and the commitment to addressing long-running grievances. We aver that, to ignore a systemic health crisis in the face of a pandemic is to be cynical about death. What was required of leadership was a compassionate approach to its citizens; a compassionate approach that recognised that it is the constitutional mandate of the state to provide health care for its citizens. Butler (2020b), in a YouTube lecture on nonviolence, indicts the United States government for failing to make health a public good for the benefit of the people of colour, and the over 28 million Americans who have no medical insurance.

Zimbabwe presents an interesting case, in that health care workers found themselves at the receiving end of both a cynical government and segments of the population who stigmatised health care workers as potential transmitters of the virus. The media reported about health workers being issued with eviction notices from their rented premises because their landlords were afraid of being infected by these supposed carriers of the virus. A local daily paper, Chronicle (Chitumba, 2020), cited the secretary general of the Zimbabwe Nurses Association as saying, nurses "are being evicted simply because they are health workers and the landlords suspect that they are carriers of COVID-19". There were similar reports from Malawi, where it was reported that health workers were being prevented from using public transport, insulted in the street, and evicted from rented apartments (Bagcchi, 2020).

Interestingly, experiences in the United Kingdom were remarkably different, as Sarkar (cited by Bagcchi, 2020) explains: "In the UK, we were fortunate not to have stigma around healthcare workers' possibility of catching COVID. Instead of turning on against us, our neighbours truly appreciated the work we have been doing". Such a display of compassion is in sharp contrast with what happened in Harare, Zimbabwe's capital city. The stigma was not confined to health personnel, as there was a media report that one street in the suburbs of Harare was renamed 'Corona Road' after a resident living along the street had been diagnosed with the virus (Bagcchi, 2020). People reportedly avoided using the street for fear of getting infected. A daily paper in Zimbabwe, Newsday $(2020$, p..2), reported that a recovered patient, Saul Sakudya of Ruwa, on the outskirts of Harare, remained in isolation sparking trauma and stigmatisation. The above incidents of stigmatisation prompted a survivor of the coronavirus to appeal as follows:

"We are all at risk of contracting the COVID-19 virus and moreso, health workers who, despite the risk, continue to offer their services to the ailing. All over the world, we witness standing ovations for health workers who stand in the line of fire against this virus, but in Zimbabwe, we get accused of endangering lives by gallivanting the streets".

The above incidents are an indication of the glaring lack of compassion among the general population in Zimbabwe. This behaviour is in stark contrast to the collective expressions of appreciation that were being witnessed in other countries, such as the United Kingdom. At the same time, it was a flagrant violation of the World Health Organization's (2020) appeal for "compassion and kindness" towards infected people in the publication, Mental Health and Pyschosocial Considerations during the COVID-19 Outbreak:

"Be empathetic to all those who are affected, in and from any country. People who are affected by COVID-19 have not done anything wrong, and they deserve our support, compassion and kindness" (p.3).

The pedagogy of compassion we argue for in this paper is intended for the "the weakest, for those whom society condemns to misery and the status of outcast, those whose dignity has been taken away," (Ruiz \& Minguez, 1999, p. 7). It is against the backdrop of incidents of stigma that we seek to foreground a pedagogy of compassion that is founded on the principles of Ubuntu, to counteract the debilitating moral crisis that is manifested by such stigma. We specifically draw on Ubuntu, which is an indigenous philosophy that emphasises our humanness and collective coexistence on this Earth. In recognising this Earth is an endowment to all posterity, Ubuntu recognises and accepts the precarity of all lives and, thus, regards all life as sacred. Ubuntu is, thus, a philosophy that is decidedly at odds with the idea of the differential grievability of life, which arises because of the politics of pandemics that is driven by the profit motive.

The essence of Ubuntu is captured graphically in the aphorism that: I am. Because we are. This aphorism emphasises interdependence, and living together. As Oviawe (2016, p. 3) explains,

"Ubuntu is a philosophy of being that locates identity and meaning-making within a collective approach as opposed to an individualistic one. As a result, the individual is not independent of the collective; rather, the relationship between a person and her/his community is reciprocal, interdependent and mutually beneficial".

It is these notions of Ubuntu that resonate with the notion of the common precarity of all lives, thus, making it a suitable basis for a pedagogy of compassion. Because Ubuntu is imbued with a moral imperative to care for the wellbeing of all, it offers useful lessons that could help to combat the pandemic. For example, the rather stunning allegations of corruption levelled against Zimbabwean government officials, involving abuse of funds intended for the procurement of medical equipment, indicate a glaring lack of Ubuntu, and the absence of a pedagogy of compassion. Reportedly widely in the media, the scandal resulted in the dismissal of the country's Health minister, Dr Obadiah Moyo (Dzenga, 2020). That funds intended for the alleviation of the suffering of COVID-19-infected patients could find their way into private hands represents the 'politics of pandemics', which involves individuals and companies seeing opportunities for 
profiteering in times of crisis. It is our argument that only a pedagogy of compassion can help to restore the moral fibre that Zimbabwean society desperately needs.

Incidents that illustrate an absence of compassionate leadership in the face of the COVID-19 pandemic abound in Zimbabwe. For example, a leadership that demands that schools reopen when the basic safety needs that guarantee life and protection from the spread of the virus are not being met, does not indicate compassion. Risking the lives of learners and their teachers, as well as their immediate families, shows politicians regard these lives as less grievable, and therefore lose-able. A pedagogy of compassion that draws on Ubuntu rejects a politics of life that states that social and economic conditions determine whose lives are lose-able and whose lives are worth saving. The need for a pedagogy of compassion is, thus, heightened by the precarity of life on this Earth.

\section{CONCLUSIONS}

This paper sought to illustrate the ways in which a pedagogy of compassion framed on the principles of Ubuntu could help to enhance living in the face of the precarity of life. Even though the pandemic curve may be flattening, and the numbers of people dying decreasing, the imperative to be compassionate towards each other remains important. Our mutual interdependence and mutual vulnerability is a call for vigilance, so that we always seek to protect life, for all lives are grievable. The entrenched politics of pandemics and the politics of life ought to give way to a reimagined politics of compassion.

The World Health Organizaton's director-general, Dr Tedros Adhanom Ghebreyesus, has, throughout the pandemic, maintained a steadfast approach to the pandemic, and his public speeches have been the epitome of a combative ontology of compassion. A pedagogy of compassion remains a powerful weapon, through which we can hope to combat precarity in all its forms. The COVID-19 pandemic serves as grim reminder of the precarity of all humanity and the imperative to build more just societies. The principles of Ubuntu constitute a powerful foundation for a reimagined pedagogy of compassion that has potential to give succour to all. In the end, we are all aware of our interdependence, and that, through expressions of collective solidarity that cut across race and gender and all forms of bigotry, we can contribute to care and promote the wellbeing of humanity. It has taken a pandemic of this magnitude to remind Zimbabweans, and the world, of the imperative of a pedagogy of compassion.

\section{ACKNOWLEDGEMENT}

This research was made possible through the National Research Fund (NRF Grant Number 129837. All views expressed here are of the authors and do not represent the position of the funder.

\section{REFERENCES}

1stTV (2020, April 19). Dying alone with no family around the evils of corona virus [Post by Dr. Masimba Mavaza]. Facebook. https://www.facebook.com/1stTV/posts/dying-alonewith-no-family-around-the-evils-of-corona-virusbydr-masimba-mavaza-/1924415704358571/.

Bagcchi, S. (2020). Stigma during the COVID-19 pandemic. The Lancet Infectious Diseases, 20(7), 782. DOI: https://doi.org/10.1016/S1473-3099(20)30498-9.

Butler, J. (2004). Precarious life: The powers of mourning and violence. Verso.

Butler, J. (2009). Frames of war. When is life grievable? Verso.

Butler, J. (2020, July 29). Judith Butler: On COVID-19, the politics of non-violence, necropolitics, and social inequality. Verso [Blog]. Retrieved from https://www.versobooks.com/blogs/4807-judithbutler-on-covid-19-the-politics-of-non-violencenecropolitics-and-social-inequality

Chitumba, P. (2020, May 18). Nurses face stigmatisation for role as Covid-19 frontline workers. Chronicle. Retrieved from https://www.chronicle.co.zw/nursesface-stigmatisation-for-role-as-covid-19-frontlineworkers/

Claravall, E. B., \& Evans-Amalu, K. (2020). Self-regulation, empathy, and compassion: A critical triad to develop anti-racist digital citizenship in the time of pandemic. Journal of International Social Studies, 10(2), 44-59.

Connell, R. (2020). COVID-19/Sociology. Journal of Sociology, 56(4), 1-7. DOI: $10.1177 / 1440783320943262$.

Dzenga, L. (2020, July 8). Health minister Moyo sacked. The Herald. Retrieved from https://www.herald.co.zw/health-minister-moyosacked/.

Dodds, K., Castan Broto, V., Detterbeck, K., Jones, M., Mamadouh, V.,Ramutsindela, M., Varsanyi, M., Wachsmuth, D., \& Woon, C. Y. (2020). The COVID-19 pandemic: territorial, political and governance dimensions of the crisis. Territory, Politics, Governance, 8(3), 289-298. DOI: 10.1080/21622671.2020.1771022.

Estelles, M \& Fischam, G.M (2020). Imagining a PostCOVID-19 Global Citizenship Education. Práxis Educativa, Ponta Grossa, v. 15, e2015566, p. 1-14.

Gibson, S., \& Cook-Sather, A. (2020). Politicised compassion and pedagogical partnership: A discourse and practice for social justice in the inclusive academy. International Journal for Students as Partners, 4(1), 16-33. https://doi.org/10.15173/ijsap.v4i1.3996.

Jansen, J. (2009). Bearing Whiteness: A pedagogy of compassion in a time of troubles, Education as Change, 12:2, 59-

75, DOI: $10.1080 / 16823200809487207$.

Kaligayahan, K. (2020). \#WeHealAaOne. Available at https://www.govserv.org/PH/QuezonCity/109736034015832/Barangay- 
Kaligayahan?cv=1\&sessionid $=8$ b985c4baa2240da9a5a27f44873b2dd

Kapiriri, L., \& Ross, A. (2020). The politics of disease epidemics: A comparative analysis of the SARS, Zika, and Ebola outbreaks. Global Social Welfare, 7(1), 33-45. https://doi.org/10.1007/s40609-0180123-y

Maarouf, Belghazi \& Maarouf (2020). COVID - 19: A Critical Ontology of the present, Educational Philosophy and Theory, (pp 1-20) DOI: 10.1080/00131857.2020.1757426.

Moisio, S. (2020). State power and the COVID-19 pandemic: the case of Finland. Eurasian Geography and Economics, 61(4-5), 598-605. DOI: $10.1080 / 15387216.2020 .1782241$.

Newsday. (2020, April 28). Govt jolted to assist COVID-19hit Ruwa family. Newsday. Retrieved from URL.www.newsday.co.zw

NPR. (2020, April 28). Blue Angels and Thunderbirds salute New York Coronavirus responders with flyover. NPR Coronavirus Updates. Retrieved from https://www.npr.org/sections/coronavirus-liveupdates/2020/04/28/847289505/blue-angels-andthunderbirds-salute-new-york-coronavirusresponders-with-flyover

Oviawe. J. (2016). How to rediscover the Ubuntu paradigm in education. International Review of Education, 62, 110. DOI: $10.1007 / \mathrm{s} 11159-016-9545-\mathrm{X}$

Ruiz, P. O., \& Minguez-Vallejos, R. (1999). The role of compassion in moral education. Journal of Moral Education, 28(1), 5-17. DOI:10.1080/030572499103278.

Santiago, A. M., \& Smith, R. J. (2020). Community practice, social action, and the politics of pandemics. Journal of Community Practice, 28(2), 89-99. DOI: 10.1080/10705422.2020.1763744.

Vincent, D. (2020, April 17). Africans in China: We face coronavirus discrimination. BBC News. Retrieved from https://www.bbc.com/news/world-africa52309414.

World Health Organization (2020, March 18). Mental health and psychosocial considerations during the COVID19 outbreak. WHO. Retrieved from https://www.who.int/docs/defaultsource/coronaviruse/mental-healthconsiderations.pdf.

World Health Organization (2020, July 23). WHO DirectorGeneral's opening remarks at the media briefing on COVID-19. WHO [Media briefing]. Retrieved from https://www.who.int/directorgeneral/speeches/detail/who-director-general-sopening-remarks-at-the-media-briefing-on-covid-19--23-july-2020.

Zembylas, M. (2013a). The "crisis of pity" and the radicalization of solidarity: Toward critical pedagogies of compassion. Educational Studies: A Journal of the American Educational Studies Association, 49(6), 504-521.
Zembylas, M. (2013b). Pedagogies of hauntology in history education: Learning to live with the ghosts of disappeared victims of war and dictatorship. Educational Theory, 63(1), 69-86.

Papastephanou, M., Zembylas, M., Bostad, I., Oral, S, B., Drousioti, K., Kouppanou, A. Strand, T., Kenneth Wain, K., \& Peters, M. A. (2020): Philosophy of education in a new key: Education for justice now, Educational Philosophy and Theory, DOI:`10.1080/00131857.2020.1793539.

Zenda, C. (2020, August 21). Can Zimbabwe fight COVID-19 without doctors and nurses? FairPlanet. Retrieved from https://www.fairplanet.org/story/canzimbabwe-fight-covid-19-without-doctors-andnurses/ 